\title{
Continuous infusion of dipyrone in bitches in the intraoperative period: cardiorespiratory effects
}

\section{Infusão continua transoperatória de dipirona em cadelas: efeitos cardiorrespiratórios e analgésicos}

\author{
Rochelle Gorczak ${ }^{1 *}$; Marilia Avila Valandro $;$; Bibiana Welter Pereira2; \\ Thaline Segatto2; Diego Vilibaldo Beckmann ${ }^{3}$; Roberto Thiesen ${ }^{3}$
}

\section{Highlights}

Continuous infusion of dipyrone in dogs in the intraoperative period.

Control perioperative pain in elective $\mathrm{OH}$ using dipyrone as an adjuvant analgesic.

Adjuvant drugs to enhance analgesia.

A drug that does not alter cardiorespiratory parameters when administered by $\mathrm{Cl}$.

\begin{abstract}
Dipyrone is an effective analgesic for managing moderate or severe postoperative pain and can be used alone for mild pain or in combination with other analgesics for any type of pain. This study aimed to examine the administration of dipyrone by continuous infusion $(\mathrm{Cl})$ as an adjuvant analgesic in the intraoperative period for bitches undergoing elective ovariohysterectomy $(\mathrm{OH})$ and its effect on these patients' cardiorespiratory parameters. Twenty bitches underwent an elective $\mathrm{OH}$ procedure. The pre-anesthetic agent was a combination of acepromazine and morphine. Propofol was used to induce anesthesia, and isoflurane was used for maintenance. Subsequently, the animals were randomly allocated into two groups: the dipyrone group (DG) received a bolus dose of dipyrone (25 mg kg-1) by Cl at a rate of $10 \mathrm{mg} \mathrm{kg}^{-1} \mathrm{~h}$, and the control group (CG) received a bolus dose and a $\mathrm{Cl}$ of $0.9 \% \mathrm{NaCl}$ solution, both groups at a rate of $5 \mathrm{~mL} \mathrm{~kg}{ }^{-1} \mathrm{~h}$. The parametric variables were analyzed by ANOVA, followed by Tukey's test $(p<0.05)$. The paired t-test $(p<0.05)$ was used for comparison between the groups. Statistical differences were observed for heart rate, systolic, diastolic, and mean arterial pressure, respiratory rate, and blood glucose between the periods in both groups. There were differences only in the basal values of MAP between the groups; however, most values remained within the physiological range for the species. Using the drug as an adjuvant to anesthesia did not alter cardiorespiratory parameters, and it can be used as an adjuvant in analgesia during the intraoperative period of $\mathrm{OH}$.
\end{abstract}

Key words: Anesthesia. Dog. Pain. Metamizole.

1 Profs. M.e, Faculdade de Veterinária do Centro Universitário Ritter dos Reis, UNIRITTER, Porto Alegre, RS, Brazil. Email: rochellegorczak@gmail.com; mavalandro@gmail.com

2 Self-employed Veterinarian, Brazil. E-mail: bibianactbm@hotmail.com; tha.segatto@gmail.com

3 Profs. Drs., Curso de Medicina Veterinária, Universidade Federal do Pampa, UNIPAMPA, Uruguaiana, RS, Brazil. E-mail: dvbeckmann@hotmail.com; betothiesen@hotmail.com

* Author for correspondence

Received: May 21, 2021 - Approved: Dec. 17, 2021 


\section{Resumo}

A dipirona é um analgésico eficaz para o manejo da dor pós-operatória moderada ou grave, podendo ser utilizada isoladamente em dores leves ou associada a outros analgésicos em qualquer tipo de dor. O presente estudo teve como objetivo avaliar a utilização de infusão contínua (IC) de dipirona no período transoperatório de cadelas submetidas à Ovariohisterectomia $(\mathrm{OH})$ eletiva como adjuvante analgésico, avaliando seu efeito sobre parâmetros cardiorrespiratórios desses pacientes. Para o estudo, 20 cadelas foram submetidas ao procedimento de $\mathrm{OH}$ eletiva. A medicação pré-anestésica foi composta pela associação de acepromazina e morfina, seguida da indução com propofol e manutenção com isofluorano. Posteriormente, os animais foram alocados, aleatoriamente, em dois grupos: dipirona (GD), que receberam bolus de dipirona (25 mg kg-1) seguido da IC do fármaco na taxa de $10 \mathrm{mg} \mathrm{kg}^{-1} \mathrm{~h}$, e grupo controle (GC), cujos animais receberam o bolus e IC de solução de $\mathrm{NaCl}$ 0,9\%, ambos os grupos na velocidade de 5 $\mathrm{mL} \mathrm{kg}{ }^{-1} \mathrm{~h}$. Variáveis paramétricas foram analisadas pela ANOVA seguida pelo teste de Tukey $(p<0,05)$ e comparadas entre os grupos pelo teste t pareado $(p<0,05)$. Foram observadas diferenças estatísticas entre os momentos em ambos os grupos em relação à FC, FR, PAS, PAM, PAD e glicemia. Entre os grupos, houve apenas diferenças nos valores basais de PAM, no entanto, a maioria dos valores manteve-se dentro da faixa considerada fisiológica para a espécie. A utilização do fármaco como adjuvante a anestesia não alterou os parâmetros cardiorrespiratórios, podendo ser utilizado como adjuvante na analgesia durante o transoperatório de $\mathrm{OH}$.

Palavras-chave: Anestesia. Cão. Dor. Metamizol.

\section{Introduction}

According to International Association for the Study of Pain [IASP] (2021), the definition of analgesia is the absence of pain in response to stimulation that would normally be painful. The drugs used for this purpose generate their action from the central nervous system and interfere in different stages of pain transmission in the spine, nerves, and nerve fibers (Fantoni \& Martins, 2011). Providing adequate analgesia is paramount to the patient's comfort (McKune, Murrell, Nolan, White, \& Wright, 2015).

Dipyrone, also known as metamizole, is a non-opioid analgesic drug used to manage different pains in small animals including postoperative, acute, and visceral pain (Giorgi et al., 2018; Hanson \& Maddison, 2010;
Morgan \& Imagawa, 2011). Some authors also classify it as a pyrazolone within the group of nonsteroidal anti-inflammatory drugs (NSAIDs), but it offers inadequate analgesia for moderate to severe postoperative pain and it can control mild to moderate visceral pain (Hanson \& Maddison, 2010; Schütter, Tünsmeyer, \& Kästner, 2015). However, it was effective in managing moderate to severe postoperative pain in humans (Derry, Faura, Edwards, McQuay, \& Moore, 2010). The combination of dipyrone with opioids generates several benefits for the patient and may reduce the dose and adverse effects of both as a consequence (Morgan \& Imagawa, 2011).

The mechanism of analgesic action of this drug is not yet fully understood as it acts both on the peripheral and central 
nervous systems and at different levels in the processing of pain information(Vale, 2006). The analgesic effect may be partially mediated by a dual mechanism of action involving inhibition of cyclooxygenase-3 enzyme activity and stimulation of cannabinoid receptors (Giorgi et al., 2018). Biotransformation is hepatic and the elimination half-life in dogs is 5-6 hours (Hanson \& Maddison, 2010). Excretion is renal (Morgan \& Imagawa, 2011) and does not cause nephrotoxicity, even in critically ill patients (Lamont \& Mathews, 2014). Although the use of dipyrone in human medicine is controversial in some countries due to its possible association with cases of agranulocytosis (Schütter et al., 2015), research in different locations has found that the risk of this disease is very low (Bassanezi \& Oliveira, 2006), and its use is authorized in cats and dogs (Hanson \& Maddison, 2010). It can be administered by different routes, but intravenous (IV) administration of bolus doses is the most common. Continuous infusion (Cl) in hospitalized patients has also been reported to have demonstrated analgesic efficacy without side effects (Otero, 2005). There is only one report on the administration of dipyrone by $\mathrm{Cl}$ as an analgesic agent in the intraoperative period (Gorczak et al., 2016); however, no scientific study has been conducted in this regard.

The aim of this study was to evaluate the administration of dipyrone by $\mathrm{Cl}$ as an adjuvant analgesic in the intraoperative period for bitches undergoing elective ovariohysterectomy $(\mathrm{OH})$ and its effect on these patients' cardiorespiratory parameters.

\section{Materials and Methods}

The study was conducted in the Veterinary University Hospital of the Federal University of Pampa (Hospital Universitário Veterinário da Universidade Federal do Pampa - HUVet-UNIPAMPA) in Uruguaiana, Rio Grande do Sul, upon approval by the institution's ethics committee on the use of animals (Comissão de Ética no Uso de Animais - CEUA), filed under no. 007/2016.

The clinical trial was randomized, prospective, and blinded. The trial consisted of 20 bitches of different breeds aged between 9 months and 6 years with a mean weight of $16.5 \pm 9.1 \mathrm{~kg}$ that had undergone an elective $\mathrm{OH}$ procedure at HUVet-UNIPAMPA. The number of animals included in the study was determined with the aid of the Power and Samples Size Calculations ${ }^{\circledR}$ program to calculate the sample size using the unpaired t-test with a statistical power of $95 \%$.

The criterion for inclusion in the study was patients with low anesthetic risk, classified as ASA I by the American Society of Anesthesiologists. A screening consisting of general clinical and complementary examinations, including an assessment of the hematology profile (blood count and total serum protein), serum biochemistry (alanine aminotransferase, alkaline phosphatase, creatinine, and urea), electrocardiogram, and non-invasive blood pressure was conducted. The animals that presented no changes in these tests were included in the study and referred to HUVet the day before surgery for acclimation and underwent $a$ fasting period of twelve hours for food and two hours for water prior to the procedure. 
The animals were randomly divided into two groups: the dipyrone group (DG; $\mathrm{n}=10$ ) received a bolus dose of the drug (25 $\mathrm{mg} \mathrm{kg}^{-1}$ ) intravenously (diluted in $3 \mathrm{ml}$ of $0.9 \%$ $\mathrm{NaCl}$ ) and by $\mathrm{Cl}$ at a rate of $10 \mathrm{mg} / \mathrm{kg} / \mathrm{h}$, which was diluted so that the infusion rate was $5 \mathrm{~mL}$ $\mathrm{kg}^{-1} \mathrm{~h}$, with a syringe pump, and the control group ( $C G ; n=10$ ) received a bolus dose of $0.9 \% \mathrm{NaCl}$ solution by $\mathrm{Cl}$ in the same volumes as DG. The evaluators of the parameters and intraoperative analgesia were always the same and were not aware of the group that the patient belonged to. The surgical team also remained the same throughout the study to standardize the technique and pain stimulus.

The pre-anesthetic agent was a combination of morphine (0.3 $\left.\mathrm{mg} \mathrm{kg}^{-1}\right)$ and acepromazine $\left(0.05 \mathrm{mg} \mathrm{kg}^{-1}\right)$ that was administered intramuscularly. To induce general anesthesia, propofol (mean dose, $3.95 \mathrm{mg} \mathrm{kg}^{-1}$ ) was administered intravenously and slowly until the medial palpebral reflex disappeared. This allowed for intubation, in which a tube with an adequate diameter was connected to a circular circuit with partial rebreathing. Isoflurane diluted in $100 \%$ oxygen was administered in an anesthetic circuit equipped with a vaporizer calibrated for the agent, maintaining the inhaled concentration at one minimum alveolar concentration (MAC) for the species, as measured by the gas analyzer in the multiparameter monitor. The patients were maintained in spontaneous breathing throughout the procedure.

After stabilization in the second plane of the third stage, which was determined by observing Guedel's classification, the treatments began according to the randomization. The surgical procedure was initiated $15 \mathrm{~min}$ after the treatment began. The evaluations were performed at specific times: (T0) before pre-anesthetic agent; (T1) after induction; (T2) immediately after the beginning of the procedure; exposure and ligature of the left (T3) and right (T4) ovarian pedicle; (T5) exposure and ligature of the cervix; (T6) initiation of suturing of the muscle (T7), subcutaneous tissue (T8), and skin (T9); and (T10) extubation. The cardiovascular and respiratory parameters were measured at all times: heart rate (HR) in beats per minute (bpm); systolic (SBP), diastolic (DBP), and mean arterial pressure (MAP) in $\mathrm{mmHg}$; respiratory rate $(\mathrm{RR})$ in movements per minute; and oxygen saturation (SpO2 \%). At T0, body temperature $\left(\mathrm{T}^{\circ} /{ }^{\circ} \mathrm{C}\right)$ was taken rectally. At $\mathrm{T} 1$ to $\mathrm{T} 10$, the values for the end-expiratory pressure of carbon dioxide (PEtCO2) in $\mathrm{mmHg}$, exhaled concentration of isoflurane (Etlso \%), esophageal temperature, and percentage of isofluorane vaporization were also obtained (V\%).

Blood was also collected to analyze blood glucose by colorimetry (GOD-oxidase) and lactate colorimetric assay in the immediate pre-anesthetic period \{Collection 1 (C1)\}, immediately after the procedure ended \{Collection 2 (C2)\}, and 24 hours after the procedure ended \{Collection $3(\mathrm{C} 3)$ \}.

As an analgesic parameter in the intraoperative period, the stability of $H R$, $M A P$, and RR were taken into account. In cases where there was a $20 \%$ increase in the values of these parameters, either alone or together, in comparison to the T1 values, an intraoperative rescue analgesia was administered with a bolus dose of fentanyl $\left(2.5 \mu \mathrm{g} \mathrm{kg}^{-1}, \mathrm{IV}\right)$. At the end of the surgical procedure, all animals received $0.2 \mathrm{mg} / \mathrm{kg}$ of meloxicam IM and then an oral dose of $0.1 \mathrm{mg}$ $\mathrm{kg}^{-1}$ every $24 \mathrm{~h}$ for 2 days. 
The D'Agostino-Pearson normality test was applied to examine the values obtained. To compare the values between the different times within groups, we used the one-way repeated-measures analysis of variance, followed by Tukey's multiple comparison test, when necessary. To compare the values between the groups, the unpaired t-test was used at each of the different times. The need for rescue analgesia during the intraoperative period was determined by the survival analysis, and the survival fractions were calculated by the Kaplan-Meier estimator. The survival curves of the groups were compared by the log-rank test (Mantel-Cox). All analyses were performed with the aid of the GraphPad Prisma $^{\circledR} 6.0$ software for $\mathrm{Mac}$, and the significance level was $5 \%(p<0.05)$.

\section{Results and Discussion}

Several researchers have investigated the efficacy of dipyrone as an analgesic in dogs and its effects on various organ systems especially in the immediate postoperative period (Derry et al., 2010; Imagawa et al., 2011; Zanuzzo et al., 2015). However, the literature has not documented the practice of adding dipyrone $\mathrm{Cl}$ in the intraoperative period and evaluating its anesthetic stability and contribution to the patient's analgesia.

For pre-anesthetic agent, we chose to use acepromazine, which causes muscle relaxation withoutanalgesia(Rankin, 2015), and in combination with morphine as a preemptive analgesic to promote adequate analgesia, as recommended by Ascoli, Gremião, Soares, Marsico and Segura (2009). To induct general anesthesia, propofol was chosen because of its rapid onset, short duration, and easy recovery (Berry, 2015). In this study, the dose of the induction agent was the same for both groups (3.95 $\mathrm{mg} \mathrm{kg}^{-1}$ ) and based on the recommendation by Pawson and Forsyth (2010) for premedicated dogs. For anesthetic maintenance, the inhalation agent isoflurane, which produces general anesthesia and can depress the cardiovascular and respiratory systems in a dose-dependent manner, was used in both groups (Steffey, Mama, \& Brosnan, 2015).

This study aimed to examine the continuous administration of dipyrone as an adjuvant in anesthesia during the surgical period, which was based on the study by Otero (2005), who administered dipyrone by $\mathrm{Cl}$ to manage postoperative pain in hospitalized canines (10 mg kg-1 h) and found a decrease in pain scale values without the occurrence of side effects.

During the anesthetic procedure, the patient should be monitored by assessing anesthetic depth, which is associated with cardiovascular and pulmonary control and temperature (Haskins, 2015). These variables were assessed in this study (Figure 1). No significant changes were observed in the means for the intraoperative parameters of the patients. No physiological parameter is reliable in accurately indicating pain as many factors can affect patients, such as fear and stress, and alter the assessment of pain in multifactorial scales. However, physiological signs often associated with pain, such as tachypnea, tachycardia, dilated pupils, and hypertension (McKune et al., 2015), were not observed in the means of the intraoperative parameters of the patients. 


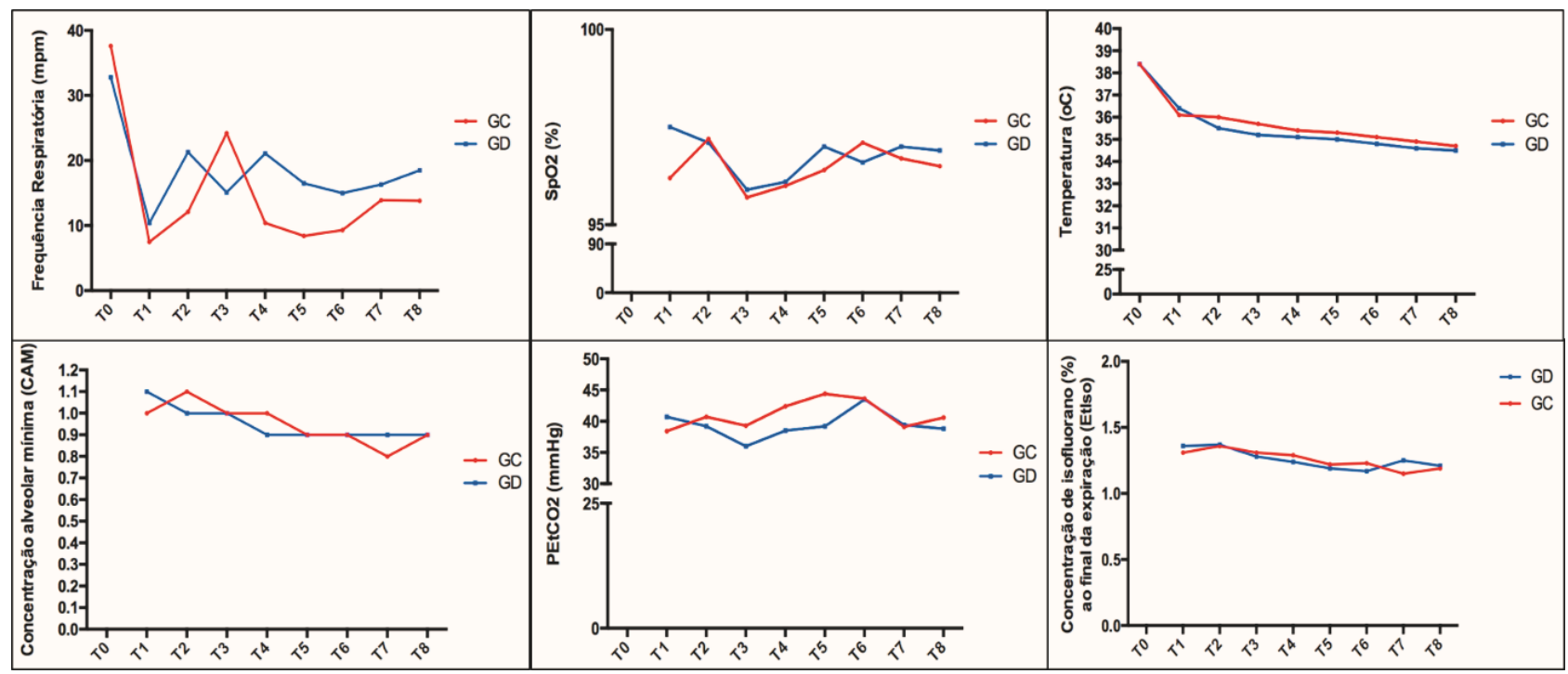

Figure 1. Graphic images demonstrating the mean variation for respiratory rate (RR), oxygen saturation $(\mathrm{SpO} 2)$, temperature $\left(\mathrm{T}^{\circ}\right)\left({ }^{\circ} \mathrm{C}\right)$, minimum alveolar concentration (MAC), partial endexpiratory pressure of carbon dioxide (PEtCO2), and exhaled concentration of isoflurane (Etlso) in the animals of the control group (CG) and the dipyrone group (DG) over the course of the intraoperative period. Uruguaiana, 2017.

As for the RR values obtained during the procedure, they did not differ significantly between the groups or the different times, although TO, when the patients were alert and awake, remained higher than the other times and within the reference range for the species (Reece, 2006). This variation in T0 is considered normal in an awake patient under stress (Bragg, Bennett, Cummings, \& Quimby, 2015). One explanation may be the great variability of this parameter, given by the high coefficients of variation found. Furthermore, the decrease in the values of the variable in both groups evidences the depressing effect of the inhalation agent on respiratory function, wherein respiratory amplitude increases and frequency decreases upon entry into a plane of anesthesia, thus maintaining the same minute volume (Massone, 2011).
As for the other variables of the respiratory system, SpO2, PEtCO2, and Etlso remained within the expected range for the anesthetized patient. However, for the anesthetic maintenance of the patients, MAC remained under the values reported in the literature for both groups, which was probably due to the prior application of neuroleptanalgesia (Steffey et al., 2015). Nevertheless, the animals remained in the surgical plane, which was the second plane of the third stage of Guedel's classification (Haskins, 2015). No variance was observed between the different times and the groups for all of these variables. Moreover, V\% in this study was higher at T1 due to a greater need for general anesthesia to stabilize the patient at the beginning of the procedure, but it did not present a significant difference 
and remained within the normal range (1-3\%) during the procedure (Bednarski, 2015).

As for temperature, the values observed after the beginning of the anesthetic procedure were below the normal limit considered for the species (Bragg et al., 2015; Massone, 2011), decreasing by approximately $3.5^{\circ} \mathrm{C}$, which can be explained by the reduction in basal metabolic rate and the arterial and venous vasodilation caused by the administered drugs. Hypothermia is a particularly common complication in animals undergoing surgical procedures. Due to the drop in the patient's temperature, their recovery often becomes impaired with a prolonged return to consciousness, excitement in recovery, collapse, prolonged hypothermia, reduced consciousness after a normal recovery, and renal failure (Haskins, 2015). The animals in the study did not present these signs, although they did present a decrease in body temperature.

In this study, HR was higher at baseline because the animals were awake and under stress at that moment. The decrease in the cardiovascular parameters was an expected effect of the general depression caused by the general anesthesia. However, the mean values remained within the physiological range for the species (Haskins, 2015; Massone, 2011). Furthermore, no difference was identified between groups, which corroborates Zanuzzo et al. (2015), who also used dipyrone prior to the procedure and obtained similar results.
In this study, the SBP, DBP, and MAP values remained stable. However, in both groups at T1 and T2, soon after induction, mild hypotension was observed, as demonstrated by the values in Table 1 . As for measuring the patients' BP, Massone and Nunes (2011) reported that the invasive measurement is more reliable, as performed in the intraoperative period of this study, but it is not indicated when the patient was awake, due to the high risk of hematomas and the need to keep the patient still. Thus, the noninvasive measurement is indicated, which was performed at the time the baseline preanesthetic parameters (TO) were collected.

The values of the SBP, DBP, and MAP can vary according to the level of stress, the patient's position, and the measurement technique. In this study, the SBP, DBP, and MAP values remained within the physiological range for the species (Haskins, 2015). Exceptions occurred at T1 and T2, right after induction, wherein mild hypotension was observed. This probably occurred because of the effect of the previously administered drugs, which are known to cause vasodilation, such as propofol (Berry, 2015; Pawson \& Forsyth, 2010) and acepromazine (Rankin, 2015). In an anesthetic procedure, physiologically MAP is considered to be the most important as it represents the average pressure for tissue perfusion and the average afterload to the heart. Its values should be maintained above $80 \mathrm{mmHg}$ (Berry, 2015), which did not occur at T1 and T2. 
Table 1

Mean values and standard deviations for the systolic, mean, and diastolic blood pressure of bitches that received a continuous infusion of dipyrone in the intraoperative period. $n=20(D G=10, C G=10)$. Uruguaiana, 2017

\begin{tabular}{ccccccc} 
& \multicolumn{2}{c}{ PAS } & \multicolumn{2}{c}{ PAM } & \multicolumn{2}{c}{ PAD } \\
\hline & GD & GC & GD & GC & GD & GC \\
T0 & $142,9 \pm 29,1^{\text {aef }}$ & $132 \pm 28,3^{\text {ac }}$ & $111,6 \pm 23,2^{\text {adeA }}$ & $102,6 \pm 17,4^{\text {acdB }}$ & $96 \pm 22,4^{\text {ad }}$ & $87,9 \pm 16,3^{\text {ad }}$ \\
T1 & $89,9 \pm 18,1^{\text {bd }}$ & $85,2 \pm 12,1^{\mathrm{b}}$ & $64,4 \pm 17,3^{\text {b }}$ & $63,5 \pm 11,1^{\mathrm{b}}$ & $51,8 \pm 18,3^{\text {bc }}$ & $51,4 \pm 11,1^{\text {b }}$ \\
T2 & $95,9 \pm 19,7^{\text {ab }}$ & $102,2 \pm 13^{\text {acd }}$ & $74,8 \pm 16,9$ & $74,5 \pm 14,2^{\text {bc }}$ & $62,6 \pm 15,5$ & $63,9 \pm 13,3^{\text {bc }}$ \\
T3 & $119,7 \pm 19,7^{\text {c }}$ & $126,2 \pm 22,2^{\text {a }}$ & $98,6 \pm 19,8^{\text {cd }}$ & $99,3 \pm 18,4^{\text {de }}$ & $85,9 \pm 20,7^{\text {d }}$ & $86,6 \pm 17,4^{\text {d }}$ \\
T4 & $114,9 \pm 19,7^{\text {cde }}$ & $112,1 \pm 20,6^{\text {ac }}$ & $91 \pm 16,9^{\text {d }}$ & $87,7 \pm 18,8^{\text {ce }}$ & $76,8 \pm 19,5^{\text {d }}$ & $76,1 \pm 18,9^{\text {acd }}$ \\
T5 & $108,8 \pm 21,7$ & $105,5 \pm 16,4^{\text {cd }}$ & $85,2 \pm 19,7^{\text {bce }}$ & $82,3 \pm 13,1^{\text {bc }}$ & $72,1 \pm 20^{\text {ad }}$ & $70,9 \pm 11,3^{\text {ac }}$ \\
T6 & $102,8 \pm 18,5^{\text {bf }}$ & $95,5 \pm 18,1^{\text {bd }}$ & $80,5 \pm 17,4^{\text {be }}$ & $75,2 \pm 14,3^{\text {bc }}$ & $68,3 \pm 17,7^{\text {ab }}$ & $63,4 \pm 15,7^{\text {ab }}$ \\
T7 & $99,4 \pm 20^{\text {ab }}$ & $102,3 \pm 10^{\text {cd }}$ & $79,4 \pm 17,1^{\text {be }}$ & $78 \pm 11^{c}$ & $67,3 \pm 17^{\text {ab }}$ & $68,5 \pm 11,2$ \\
T8 & $105,6 \pm 21,5^{c}$ & $105,1 \pm 11,3^{\text {acd }}$ & $83,2 \pm 17,5^{\text {be }}$ & $76 \pm 9,7^{\text {b }}$ & $70,4 \pm 17,3$ & $64,7 \pm 11^{\text {b }}$
\end{tabular}

Different lowercase letters between the rows represent differences between the different times within the groups (Tukey's test, $p<0.05)$. Different uppercase letters between the columns represent differences between the groups at each time (unpaired t-test, $p<0.05$ ).

During the intraoperative period, rescue analgesia was administered in six animals (30\%), including four dogs (20\%) in the CG, and no significant difference was observed (Figure 2). Rescue analgesia is a strategy applied when the patient demonstrates a greater need for analgesia, and it should be administered during the procedure or in postoperative care if the animal presents with pain. Different drugs can be used for this analgesia. The main ones are opioids, among which fentanyl is an opioid agonist much more potent than morphine, and the duration of its effect is short (about 30 min) when administered intravenously (bolus dose), intramuscularly, or subcutaneously. Accordingly, the drug is indicated for studies in which analgesic evaluations are performed (Kukanich \& Wiese, 2015), and it is the drug of choice administered in animals that require intraoperative rescue analgesia.

The blood glucose level remained in the upper limit at $\mathrm{C} 2$, unlike $\mathrm{C} 1$ and $\mathrm{C} 3$, where it remained within the normal range. The results for blood glucose and lactate levels are exhibited in Table 2. This change in the glycemic index was probably due to the use of inhalation agents that may cause hyperglycemia (Horber et al., 1990). Both groups were maintained with the isoflurane agent, and the glucose levels immediately at the end of the procedure were slightly higher than those in the other times. In addition, the higher stress levels caused by the greater surgical nociceptive stimulus can result in hyperglycemia in some animals due to the secretion of catecholamines (Fox, Mellor, Firth, Hodge, \& Lawoko, 1994). Although lactate 
is not a specific marker, it is considered an indicator of anaerobic metabolism and is used to identify ischemia and tissue inflammatory lesions (Haskins, 2015). It remained within the physiological range for the species throughout all the periods.

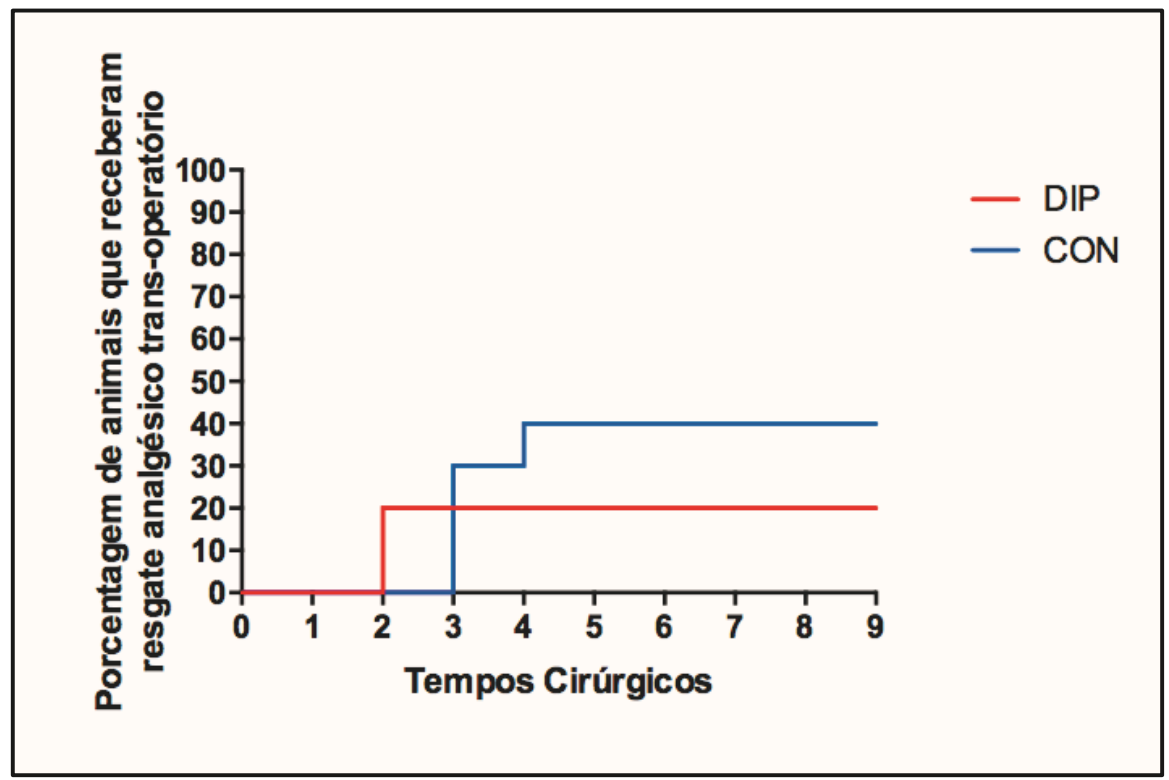

Figure 2. Graphic image demonstrating the rescue analgesia administered intraoperatively in the animals of the control group (CG) and the dipyrone group (DG). Uruguaiana, 2017.

\section{Table 2}

Mean values and standard deviations for lactate and glucose levels of bitches that received a continuous infusion of dipyrone prior to the procedure (C1), immediately after the procedure (C2), and 24 hours after the procedure (C3). $n=20(D G=10, C G=10)$

\begin{tabular}{ccccc} 
& \multicolumn{2}{c}{ Lactato $(\mathrm{mmol} / \mathrm{L})$} & \multicolumn{2}{c}{ Glicose $(\mathrm{mg} / \mathrm{dL})$} \\
\hline & $\mathrm{GD}$ & $\mathrm{GC}$ & $\mathrm{GD}$ & $\mathrm{GC}$ \\
$\mathrm{C} 1$ & $1,76 \pm 0,59$ & $1,68 \pm 0,4$ & $91,6 \pm 10,1^{\mathrm{a}}$ & $90,3 \pm 10,4^{\mathrm{a}}$ \\
C2 & $1,47 \pm 0,52$ & $1,35 \pm 0,4$ & $117,3 \pm 17^{\mathrm{b}}$ & $129,5 \pm 25,9^{\mathrm{b}}$ \\
C3 & $1,2 \pm 0,26$ & $1,67 \pm 0,67$ & $95,3 \pm 9,11^{\mathrm{a}}$ & $96 \pm 16,2^{\mathrm{a}}$
\end{tabular}

Different lowercase letters between the rows represent differences between the different times within the groups (Tukey's test, $\mathrm{p}<0.05$ ). 
At the end of the procedure, the animals in both groups received a dose of $0.2 \mathrm{mg} /$ $\mathrm{kg}$ of the NSAID meloxicam intramuscularly, followed by an oral dose of $0.1 \mathrm{mg} / \mathrm{kg}$ every $24 \mathrm{~h}$ for 2 more days, as indicated by Hanson and Maddison (2010), to control postoperative inflammatory pain.

The use of pre-anesthetic dipyrone in dogs undergoing $\mathrm{OH}$ was evaluated by Schütter et al. (2015). They concluded that the use of this drug alone as an analgesic should not be recommended. However, there is an interconnection between the mechanisms of action of dipyrone and opioids, thus indicating potentially synergistic effects between these drugs in dogs, and their combination is indicated as a pre-anesthetic agent. Flôr, Yazbek, Ida and Fantoni (2013) also note that the use of opioids with dipyrone enhances the analgesic effect of the former drug. The same combination of dipyrone and morphine (opioid) was effective in an experimental study to evaluate its antinociceptive potential in rats (López-Muñoz et al., 2008). The results of this study regarding analgesia justify the absence of differences observed in the evaluations. This study used only morphine in the $C G$, which provided analgesia for the procedure (Ascoli et al., 2009), and a combination of morphine and dipyrone in the DG, which generated satisfactory analgesia for the procedure in both groups. However, an evaluation of the enhanced effect of the opioid was not performed in this study. Moreover, contrary to the report by Zukowski and Kotfis (2009), no adverse reactions were observed in this study, which shows that it is a safe drug to administer in healthy dogs undergoing elective $\mathrm{OH}$.

\section{Conclusion}

Based on the findings of this study, $\mathrm{Cl}$ of dipyrone at a dose of $10 \mathrm{mg} / \mathrm{kg} / \mathrm{h}$ in bitches undergoing elective $\mathrm{OH}$ is safe as it does not alter these patients' cardiorespiratory parameters and laboratory evaluations. Therefore, it may constitute a new combination option in intraoperative protocols for elective $\mathrm{OH}$.

\section{Acknowledgements}

We would like to thank the team that helped execute the project: Ana Paula Ibarra, Bibiana Welter, Debora Freitas Lima, Eduardo André Lima, Gabriela Lugoch, Gabriel Tavares, Gabriel Sabioni, Natalia Horstmann Risso, Thaline Segatto, and Professor Mirela Noro.

\section{References}

Ascoli, F. O., Gremião, D. F., Soares, J. H. N., Marsico, F., \& Segura, I. A. G. (2009). La administración preoperatoria de morfina mejora la analgesia postoperatoria frente a la administración intraoperatoria en perras ovariohisterectomizadas. Cliníca Veterinaria de PEQUEÑOS animales: Revista Oficial de AVEPA, Asociación Veterinaria Española de Especialistas en Pequeños Animales, 29(2), 97-102.

Bassanezi, B. S. B., \& Oliveira, A. G. O., Fo. (2006). Analgesia pós-operatória. Revista do Colégio Brasileiro de Cirurgiões, 33(2), 116-122. doi: 10.1590/S0100-69 912006000200012

Bednarski, R. M. (2015). Dogs and cats. In K. A. Grimm, L. A. Lamont, W. J. Tranquilli, S. 
A. Greene, \& S. A. Robertson (Eds.), LUMB \& JONES' veterinary anesthesia and analgesia (5nd ed., pp. 819-826). lowa: Wiley Blackwell.

Berry, S. H. (2015). Injectable anesthetic. In K. A. Grimm, L. A. Lamont, W. J. Tranquilli, S. A. Greene, \& S. A. Robertson (Eds.), LUMB \& JONES' veterinary anesthesia and analgesia (5nd ed., pp. 277-296). lowa: Wiley Blackwell.

Bragg, R. F., Bennett, J. S., Cummings, A., \& Quimby, J. M. (2015). Evaluation of the effects of hospital visit stress on physiologic variables in dogs. Journal of the American Veterinary Medical Association, 46(2), 212-215. doi: 10.2460/ javma.246.2.212

Derry, S., Faura, C., Edwards, J., McQuay, H. J., \& Moore, R. A. (2010). Single dose dipyrone for acute postoperative pain. Cochrane Database of Systematic Reviews, 8(9), 1-48. doi: 10.1002/14651858.CD0032 27.pub2.

Fantoni, D., \& Martins, A. (2011). Analgesia para cirurgia geral. In D. Fantoni (Ed.), Tratamento da dor na clínica de pequenos animais (pp. 261-275). Rio de Janeiro: Elsevier.

Fox, S. M., Mellor, D. J., Firth, E. C., Hodge, H., \& Lawoko, C. R. O. (1994). Changes in plasma cortisol concentrations before, during and after analgesia, anesthesia and anesthesia plus ovariohysterectomy in bitches. Research in Veterinary Science, 57(1), 110-118. doi: 10.1016/0034-52 88(94)90091-4

Flôr, P. B., Yazbek, K. V. B., Ida, K. K., \& Fantoni, D. T. (2013). Tramadol plus metamizole combined or not with anti-inflammatory drugs is clinically effective for moderate to severe chronic pain treatment in cancer patients. Veterinary Anaesthesia and Analgesia, 40(3), 316-327. doi: 10. 1111/vaa.12023

Giorgi, M., Lebkowska-Wieruszewska, B., Lisowski, A., Owen, H., Poapolathep, A., Kim, T. W., \& De Vito, V. (2018). Pharmacokinetic profiles of the active metamizole metabolites after four different routes of administration in healthy dogs. Journal of Veterinary Pharmacology and Therapeutics, 41(3), 428-436. doi: 10.1111/jvp.12484

Gorczak, R., Valandro, M. A., Martins, R., Abatti, M., Rodrigues, G. I. J., \& Soares, A. V. (2016). Infusão Continua de dipirona em um cão submetido à cistotomia e nefrotomiarelato de caso. Anais do Congresso Brasileiro da Anclivepa. Goiânia, GO., Brasil, 37.

Hanson, P. D., \& Maddison, J. E. (2010). Antiinflamatórios não esteroidais e agentes condroprotetores. In J. E. Maddison, S. W. Page, \& D. B. Church (Eds.), Farmacologia clínica de pequenos animais (2a ed., pp. 282-305). Rio de Janeiro: Elsevier.

Haskins, S. C. (2015). Monitoring anesthetized patients. In K. A. Grimm, L. A. Lamont, W. J. Tranquilli, S. A. Greene, \& S. A. Robertson (Eds.), LUMB \& JONES' veterinary anesthesia and analgesia (5nd ed., pp. 86-113). lowa: Wiley Blackwell.

Horber, F. F., Krayer, S., Miles, J., Cryer, P., Rehder, K., \& Haymond, M. W. (1990). Isoflurane and whole body leucine, glucose, and fatty acid metabolism in dogs. Anesthesiology, 73(1), 82-92. doi: 10.1097/00000542-199007000-00013 
Imagawa, V. H., Fantoni, D. T., Tatarunas, A. C., Mastrocinque, S., Almeida, T. F., Ferreira, F., \& Posso, I. P. (2011). The use of different doses of metamizol for postoperative analgesia in dogs. Journal of Veterinary Anaesthesia, 38(4), 385-393. doi: 10.1111/j.1467-2995.2011.00617.x

International Association for the Study of Pain (2021). IASP taxonomy. Retrieved from https://www.iasp-pain.org/resources/ terminology/\#analgesia

Kukanich, B., \& Wiese, A. J. (2015). Opioids. In K. A. Grimm, L. A. Lamont, W. J. Tranquilli, S. A. Greene, \& S. A. Robertson (Eds.), $\angle U M B$ \& JONES' veterinary anesthesia and analgesia (5nd ed., pp. 207-226). lowa: Wiley Blackwell.

Lamont, L. A., \& Mathews, K. A. (2014). Opioides, anti-inflamatórios não esteroidais e analgésicos adjuvantes. In W. J. Tranquili, J. C. Thurmon, \& K. A. Grimm (Eds.), LUMB \& JONES: anestesiologia e analgesia veterinária (4a ed., pp. 270-304). São Paulo: Roca.

López-Muñoz, F. J., Godínez-Chaparro, B., Huerta-Cruz, J. C., Guevara-López, U., Domínguez-Ramírez, A. M., \& CortésArroyo, A. R. (2008). The antinociceptive efficacy of morphine, metamizol, or their combination in na experimental rat model with different levels of inflammatory pain. Pharmacology, Biochemistry and Behavior, 91(1), 196-201. doi: 10.1016/j. pbb.2008.07.007

Massone, F. (2011). Planos anestésicos. In F. Massone (Ed.), Anestesiologia veterinária farmacologia e técnicas texto e atlas (6a ed., pp. 33-36). Rio de Janeiro: Guanabara Koogan.
Massone, F., \& Nunes, N. (2011). Aparelhos, circuitos anestésicos e monitoramentos. In F. Massone (Ed.), Anestesiologia veterinária farmacologia e técnicas texto e atlas (6a ed., pp. 47-63). Rio de Janeiro: Guanabara Koogan.

McKune, C. M., Murrell, J. C., Nolan, A. M., White, K. L., \& Wright, B. D. (2015). Nociception and pain. In K. A. Grimm, L. A. Lamont, W. J. Tranquilli, S. A. Greene, \& S. A. Robertson (Eds.), LUMB \& JONES' veterinary anesthesia and analgesia (5nd ed., pp. 584-623). lowa: Wiley Blackwell.

Morgan, J. N., \& Imagawa, V. H. (2011). Analgésicos antipiréticos: dipirona e paracetamol. In D. Fantoni (Ed.), Tratamento da dor na clínica de pequenos animais (pp. 137-149). Rio de Janeiro: Elsevier.

Otero, P. E. (2005). O manejo da dor e a medicina veterinária. In P. E. Otero (Ed.), Dor avaliação e tratamento em pequenos animais (pp. 2-5). São Caetano do Sul: Iterbook.

Pawson, P., \& Forsyth, S. (2010). Agentes anestésicos. In J. E. Maddison, S. W. Page, \& D. B. Church (Eds.), Farmacologia clínica de pequenos animais (2a ed., pp. 83-112). Rio de Janeiro: Elsevier.

Rankin, D.C.(2015). Sedatives and tranquilizers. In K. A. Grimm, L. A. Lamont, W. J. Tranquilli, S. A. Greene, \& S. A. Robertson (Eds.), $\angle U M B$ \& JONES' veterinary anesthesia and analgesia (5nd ed., pp. 196-206). lowa: Wiley Blackwell.

Reece,W.O. (2006). Respiraçãonos mamíferos. In W. O. Reece (Ed.), Dukes fisiologia dos animais domésticos (12a ed., pp. 103134). Rio de Janeiro: Guanabara Koogan. 
Schütter, A. F., Tünsmeyer, J., \& Kästner, S. B. R. (2015). Influence of metamizole on 1) minimal alveolar concentration of sevoflurane in dogs and 2) on thermal and mechanical nociception in conscious dogs. Veterinary Anaesthesia and Analgesia, 43(2), 215-226. doi: 10.1111/ vaa.12289

Steffey, E. P., Mama, R. K., \& Brosnan, R. J. (2015). Inhalation anesthetics. In K. A. Grimm, L. A. Lamont, W. J. Tranquilli, S. A. Greene, \& S. A. Robertson (Eds.), LUMB \& JONES' veterinary anesthesia and analgesia (5nd ed., pp. 297-331). lowa: Wiley Blackwell.
Vale, N. (2006). Desmistificando o uso da dipirona. In I. L. Cavalcanti (Ed.), Medicina perioperatória (pp. 1107-1124). Rio de Janeiro: SAERJ.

Zanuzzo, F. S., Teixeira, F. J., Neto, Teixeira, L. R., Diniz, M. S., Souza, V. L., Thomazini, C. M., \& Steagall, V. M. (2015). Analgesic and antihyperalgesic effects of dipyrone, meloxicam or a dipyrone-meloxicam combination in bitches undergoing ovariohysterectomy. The Veterinary Journal, 205(1), 33-37. doi: 10.1016/j.tvjl. 2015.05.004

Zukowski, M., \& Kotfis, K. (2009). Safety of metamizole and paracetamol for acute pain treatment. Anestezjologia Intensywna Terapia, 41(3), 170-175. 
